One would have thought that enongh had been said already about the zones of the Chalk, and that especial pains would therefore be taken to attain to greater exactness in official memoirs.

C. Davies Sherborn.

\title{
MARINE SHELLS.
}

Sir,-I beg to inform the readers of the Geological Magazinis that, acting under my directions, Mr. David Nimmo, jun., and Mr. Frank White have found marine shells in the drift of the Leaze Burn, near the watershed with Logan Water, and four miles northeast of Muirkirk, in Ayrshire. The drift here is a yellowish Boulder-clay, the clay being very fine-grained and exceedingly suitable for preserving organisms. The exposed bed is 15 feet thick, rock not seen, and 1,330 feet above sea-level, and is the highest point in Scotland at which marine organisms have been found in $\begin{array}{ll}\text { the drift. } & \text { J. SMrrH. }\end{array}$

Monkredding, Kilwinning.

Sept. 1, 1902.

DEVELOPMENT OF RIVERS.

Srr,-Mr. Buckman, in his article on River Development in the August number of the Geological MaGazine, criticizes my paper published in the Quart. Journ. Geol. Soc., vol. lviii, p. 207. On two points his criticisms are well founded. My allusion to the Vale of Moreton, which was added after the writing of the paper, was made under a misapprehension, for I had not grasped the fact that the anticline was considered by Mr. Buckman to be of Inferior Oolite age. Under such circumstances it was of no use to me, for $I$ was in search of an arching up of the Chalk at a much later date. It is true also that the Vale of Moreton is wrongly placed on my map. The name was added, I think, on a proof, but the responsibility, of course, was mine. As regards the other points on which Mr. Buckman considers that $I$ have erred in matter of fact, I see no reason to modify what I wrote.

Mr. Buckman finde it very remarkable that the anticline of which I was in search should be evidenced by no more than traces. The difficulty in locating it is due to the fact that the Chalk, in which alone its effects would have been obvious, has been denuded away; that it has not been recognized in the Oolitic rocks means nothing, for it would be masked by the more pronounced movements which affected those rocks before the deposition of the Chalk, but that it existed is proved by a general consideration of the dip of such Chalk as remains. As I pointed out, the westerly rise cannot have continued indefinitely, for it would have carried the Upper Cretaceous base far above the level at which we believe it to have lain in the West of England and in Wales.

The paper by Mr. Buckman in the Proc. Cotteswold Nat., vol. xiii, p. 175, 1899-1901, which I characterized in a footnote as "transgressing the limits of legitimate speculation," was preceded, as he points out, by a paper in Natural Science, vol. xiv, p. $270,1899$. 
In view of his statement that the earlier paper gave his views in more detail, I have turned to it with some interest in the hope of finding further evidence of the changes he describes in the riversystem of England and Wales. The paper gives a clear history of the development of a river on a slope composed of rocks of different hardness and porosity, a classification of the breaches which vecur in many escarpments, and an exposition of the principles of river-capture, illustrated by examples drawn from different parts of the country. So far the account is excellent, but already an uneasy feeling arises that more evidence for the cases of river-capture quoted as examples would be desirable.

The uneasiness is far from being allayed by what follows. After briefly relating a quarrel between the Thames and the Kennet, as a result of which the former is credited with having appropriated all the Cotteswold streams, the author continues: "The Evenlode was a very large river, draining by one branch the north Welsh mountains, by the other the west side of the Pennine range. East of it was a south - easterly extension of the Dove. The Evenlode soon captured this by sending out the Cherwell as a subsequent stream; and on the other side it captured all the Cotteswold streams. The Kennet was the other important river. It originally drained Mid and some of South Wales."

On the map accompanying these statements the Derbyshire Wye, the Dove, Trent, Mersey, Weaver, Upper Dee, Upper Severn, Teme, Lug, Wye, Usk, Rhymney, and Taff rivers are shown as tributaries of the Thames. Parts of these rivers, it is true, flow in the direction of the Thames, but much of this imaginary river-system crosses the existing lines of drainage at right angles, wbile such features as the British Channel are got rid of by stating that they did not yet exist. The evidence for the existence of this river-system is of the slightest description; we are told that the rivers must have run thus, and that they must have occupied certain gaps in the Oolitic escarpment. Its restoration seems to have been effected by piecing together such portions of river-valleys as happened to fall into a suitable position on the map.

The Severn is credited with effecting the change to the system now existing. Beginning as a small stream, it captured the Taff, Rbymney, Usk, Wye, and a number of others, its remarkable career being briefly related as a statement of fact. "The further development," the author naively remarks, " may be shortly told." The Severn "started or strengthened two subsequent branches-one northwards, which captured the Shropshire and Welsh drainage, the other north-eastward-the present Warwick Avon which cut off the head-waters of the Thames tributaries from the north."

In his concluding remarks Mr. Buckman is frank. "Many of the statements in this paper may be termed mere speculation. It is fully admitted." I give these brief extracts in justification of my footnote.

A. Strahav.

Streatlex, Readisg.

August 18, 1902 . 